\title{
A SEMANTIC STUDY OF THE EFFECT OF MEANING CHANGE IN YORUBA-ENGLISH SPEAKERS
}

\author{
Badmus-Lawal, K. ${ }^{1 *}$ \& Olofinsao O. M. ${ }^{2}$ \\ ${ }^{1}$ Department of Linguistics and Languages, Federal University Oye-Ekiti, kareemahbadmus@gmail.com \\ ${ }^{2}$ Department of Linguistics and Languages, Federal University Oye-Ekiti, olukemi.olofinsao@fuoye.edu.ng
}

\begin{abstract}
.
The dynamism of language is birthed from time to time in the minds of native speakers, either consciously or unconsciously. Language is uniquely designed to fix meanings of words, and the essence of meanings is indispensable. As humans, we are directly conscious of meanings. The passage of meanings from the speaker to the hearer can vary, and the interpretation is dependent on the context, among other things. In view of this, it can be said that the dynamism of language reproduces semantic change, such that meanings canbe equally or differently interpreted because words mean different things to different people. In a society where meanings are not diffused equally, there is often a gap between the classical and contemporary generation. This semantic deviation contributed greatly to the poor development of communicative performance among native speakers of Yoruba. This work therefore, examines lexical items whose meanings have been extensively distributed to suit different contexts. The work is approached through Simak Bebas Libat Cakap technique and library research. This work focuses on the features of M.A.K. Haliday's functional theory which include new discoveries, technological words and slangs. These features are compared with their Standard British forms or meanings, and the differences are established. The data of this study was randomly selected and analyzed. It was discovered that the deviation in the meanings of some Yoruba lexical items is facilitated by the need for a new meaning, vagueness of meaning, ambiguous context, among others. The findings are suggestive of the communication gap among Yoruba-English speakers. This gap is observed between the classical and contemporary generation. In view of this, more efforts should be made by linguists and writers to preserve the dynamism and uniqueness of meaning change in Yoruba language.
\end{abstract}

Keywords: Semantics, Linguistics, Yoruba, English, Language, dynamism,

\section{Introduction}

Language changes with time and the role of time in semantic change cannot be overemphasized. Time is central to language and it has powerful effects. Thus, the existence of language is deeply rooted in time.Language changes, evolves and adapts to the need of its users. It has been acknowledged across different scholarly works that languages are ever-dynamic. The dynamism of languages can be likened to that of a chameleon. As long as the need of the speakers change, so will the language. Moreover, language change is due to the fact that language is handed down from a generation to the other. As a language is passed from a generation to the other, there are usually changes in language forms. Children also use the same physiological and cognitive endowment inlearning language. Therefore, the same patterns of change are repeatedly manifested across all languages.

Also, change in meaning is as common as change in form because as time goes on, there is loss of lexical transparency in language vocabularies. That is when a word becomes opaque. This occurred because words that are constantly used do not have the same meaning at all times. Thus, when a different intention for a word is shared by the speech community and becomes established in usage, then, a semantic change has occurred.

Semantics is the study of meaning, and meaning resides in words and structures. It is established that semantics is a linguistic study that enhances communication. The ability to communicate within and outside one's linguistic environment depends on the knowledge of the meanings of lexical items in the language. This knowledge is instilled in the native speakers of a language right from inception. 
In addition, the development of different meanings for a word automatically raises the question of whether there is an 'original' meaning. This conception is termed 'etymological fallacy' with the intention that, there is an original meaning to a word if one could trace it to the origin of the word. This conception of meaning is false, because no matter how you trace the origin of a word, there is a stage before that with a probably different meaning. This shows that language moves faster than we can imagine.

Furthermore, as time goes on, loss of lexical transparency occurs in semantic change, where a word or part of a word becomes opaque to a later generation because the meaning of such a word may be reinterpreted. Such a reinterpretation is called 'folk etymology'. This occurs on the basis of words which are similar in sound and meaning. A simple example is the Yoruba word 'ògì' which means 'pap'. This same object was first referred to as 'kókó', eventually, it was called 'ẹ̀ko' and now, it is referred to as 'ògì'.

The development of the word 'ògì' came from several stages of re-interpretation and lexical expressions. Meanwhile, 'ògì' which was re-interpreted as 'pap' which means "a cooked drink made from corn/maize", originally meant "the raw form of grinded corn that has not been made into pap through cooking". Now, the two meanings are used interchangeably for both the raw and the cooked form. This asserts to the phenomenon of 'folk etymology' that words can develop similar meanings.

In addition, semantic change has several effects on linguistic performance. The term 'linguistic performance' was introduced by Noam Chomsky in 1965 to describe "the actual use of language in concrete situations". Linguistic performance is the actual use of language in communicative event. It is used to refer to both the production as well as the comprehension of language. This refers to the idea that native speakers of a language should be able to produce as well as comprehend their language.

Yoruba is the first language for approximately 30 million West Africans, and is spoken by populations in Southwestern Nigeria, Togo, Benin and Sierra Leone. It is also one of the prominent languages and cultures of the diaspora, it greatly impacts the social, cultural and religious lives of millions of people in countries outside Africa, such as Brazil, Venezuela, Cuba, Trinidad and Tobago, and Haiti. In Yoruba language, the lexical forms of object and concepts changes in the course of time and the meaning of words are not always retained. Words give rise to new meanings and some old meanings are mostly in use.

Generally speaking, a necessary condition in any language change, no matter its cause, is some connection; some association between the old form and the new. This happens when the classical generation refers to an object/expression in a different form while the contemporary generation refers to the same object using a lexical form that is entirely different from the one used by classical generation. For example, 'window' in Yoruba has different lexical forms over the years. 'Window was first called 'móràsáná' and then, 'férèmù'. Now, it is referred to as 'fèrèsé'. The development of the word 'window' has passed through different stages such as; móràsáná-férèmù-fèrèsé, all of which refer to the object; 'window'.

Inmost cases, there is no connection between the old form and the new; 'Mo je dòdò'/‘Mo je dòdò omo yen' (I ate plantain/I admire that child). At other times,both forms are used interchangeably; 'ògì'/ệkọ’ (grinded corn/pap). There are also cases where the old form goes into extinction, while retaining the new; 'òsùpá/ọdún' (moon/year).

In conclusion, situations also exist when both the old and new meanings are retained. This is followed by the act where the old forms/meanings are mostly used by the elderly speakers. This is termed as the core/ 'ijìnlè Yoruba' among native speakers. Young speakers are left with the new forms/meanings which are often 
perceived as fragments of the Yoruba language, by most elderly speakers. As a result, younger speakers also carve out new meanings of lexical items that are totally obscene to the classical generation. As a consequence, there is usually a communication gap between the classical and the contemporary generation.

\section{Statement of the research problem}

In an attempt to study Yoruba language, one realizes the extent of its deviation in terms of meaning evolution of some lexical items. Some words had recently undergone semantic change, thereby making them more ambiguous within a sentence.

Semantic change affects the performance of native speakers, no matter the level of competence. These semantic changes are mostly influenced by time and the chronological age of speakers; the classical generation versus the contemporary generation.

Furthermore, words experience semantic change which is the hallmark for new meanings. The new meaning of a word can even represent an entirely different object/concept in the language. As a result, the two meanings compete and appear ambiguous within a sentence. Sometimes, these words cannot be righty interpreted, even in context.

For the classical generation, such semantic changes are hard to commit to memory. Sometimes, context might be the only saving grace. At other times, the classical generation might not be able to keep track of the semantic changes in lexical items and phrases in their native language. This contributes to the contemporary generation taking notes of the new meanings generated by semantic change, thereby losing the former ones unconsciously. In addition, it has been observed that some Yoruba lexical items have different meanings attached to them by native speakers as influenced by the Nigerian context and culture. These semantic deviations contribute largely to the poor development of grammatical competence among the native speakers of the language, as the meanings attached to these lexical items/phrases are more of those obtained in the Nigerian environment. This makes it difficult for non-native of the language to understand utterances.

Moreover, the poor comprehension of utterances leads to the development of poor linguistic performance in any communicative event. As a result of this, a communicative event becomes another moment of analyzing lexical items, which seems futile because, at the end, the message is not understood. This leads to a breakdown in communication, since the channel of communication is incomplete without a feedback.

It is this apparent deviation from the earlier meanings that justifies this study while considering the competence and performance of native speakers in relation to the semantic changes in Yoruba language, with special reference to the semantic features of Yoruba lexical items and their usage.

The main objective of this study is to examine the peculiarity in the meanings of some Yoruba lexical items as used in the Nigerian environment. While semantic change has caught the fancy of scholars for centuries, the area of semantic change in relation to linguistic performance has not received much attention.

In conclusion, this research will contribute to all the existing literatures of evidences in semantic change. The data collected through this project has the potential to be used as basis for other research in the field. The results of this project are important to linguists because they will provide insights into the linguistic performance needs of speakers through the publication of 'The Dictionary of Semantic changes in Yoruba language', thereby 
neutralizing the negative effects of semantic change to unravel solutions to this apparent deviation. It is on this note that this study is justified.

\section{Review}

\section{Semantics}

There have been arguments on whether semantic change is a deviation or not. A lot of linguists have conducted researches and investigations to examine the existence or otherwise of semantic change. It has been established that since language is dynamic, every other aspect of a language also undergoes changes from time to time.

Furthermore, there are many literatures revealing the phonological, morphological and syntactic features of Yoruba language. It is however quite unfortunate that little attention has been paid to its semantic deviations from standard Yoruba as well as its effect in linguistic performance of native speakers.

Additionally, meaningful communication cannot be achieved by only the knowledge of the phonological, morphologicaland syntactic aspects of the language, since a communication channel is incomplete without a feedback. Yet, we can't receive a feedback without the semantic understanding of the communicative event, even in context.

Semantics is the study of meaning in a language (Lobner, 2002). According to Chambers Biographical Dictionary (1990, p. 202), the word semantics was first used by Michael Bréal in the nineteenth century to mean a range of ideas often used in natural languages to explain the issue of understanding that is associated with word selection and connotation.

Correspondingly, semantic aspect of the language needs to be given more attention, especially the area of semantic change. As stated by Firth, this is because, language is a meaningful activity and the indispensable goal of any language is the communication of thoughts and meaning (as cited in Ogunleke, 2008, p.19).

However, semantic change in words is so evident in Yoruba to the extent that some words cannot be understood by an individual who is not familiar with the changes or even by learners of the language. Although, one can sometimes ascertain that some words have more than the original meaning by the context surrounding the communicative event.

Meaning is an indispensable companion of language. Humans communicate with meanings in their minds. Yet, words mean different things to different people. Not to talk of semantic changes in such words. The study of semantic aspect of Yoruba will go a long way in enhancing communication among users of the language.

In an attempt to make a distinction between semantic change and semantic neology, Boussidan (2013) observed that "the term semantic change is generally associated with Anglo-Saxon approaches, while most European approaches uses the term 'semantic neology'. However, semantic neology, or how words acquire or lose some of their meanings, is part of semantic change which encompasses conceptual change or how new or obsolete concepts are attached to a known/new word" (p. 29).

In addition, it has been established that the methodologies used to investigate semantic changes over the years has been the same; all pointed in the same direction and of course, the same results. Magué (2006) asserted that "Despite the great variety of theoretical approaches, the study of semantic changes has gone through, the methodology remained the same: only completed semantic changes are studied, either by the analysis of 
synchronic manifestations i.e. polysemy or sets of cognates, or by the analysis of the development of a new meaning from corpus evidences".

Furthermore, one of the contribution to the theory of meaning change is the classic article by Antonie Meillet titled, "Comment les mots changent de sens?" which when translated means; "How do words change meaning?". It was published in 1906 in "Anne Sociologique". In this article, Meillet presented the outline of a sociolinguistic view of meaning change which consists in an integrated theory of innovation and diffusion. According to this theory, semantic changes arise mainly due to the fact that speech communities are heterogeneous, and that they are organized into different social groups.

Nevertheless, the society as a whole, tend to resist linguistic innovation while small groups tend to encourage innovation. As the same individual may belong to different groups, simultaneously or in succession, there is an exchange of lexemes between such groups. This is what is termed 'borrowing'. As soon as a word is extracted from its original sphere of usage and is taken up by wider circles, the new users will generally lack the knowledge available to the original group of speakers and will use the word in a less specific sense. Therefore, the moving of words from group languages to the common language and vice-versa causes semantic change.

Also, word dynamics encompasses all the semantic process of word formation, such as morphological productivity, whereas concept dynamics include all the mechanics of conceptual evolution and redistribution. This occurs when words are removed from its original frame of usage, and has evolved their meanings. The new meanings are gradually diffused into the speech community until they are widely distributed. Though, not all groups will embrace meaning change at once. The youths are generally known for embracing anything that has to do with 'change' in all spheres of life.

Also, new meanings are mostly confronted with the issue of diffusion. It has been established that somehow, a new word or meaning is relayed in communities of speakers, until it becomes part of the language either at the level of unspoken consensus or at the level of lexicology.

Thus, new words and meanings may emerge from individual innovation but their existence is rooted in a speech community, for diffusion matters. Indeed, new meanings may be said to have come into existence through language use, as stated by Traugott and Dasher (2002). This implies that a lot of changes emerge from colloquial language before being absorbed into more formal language.

Meaning seems intrinsic to a language. When we make a sentence, we combine it to have a structural meaning and communicative sense. Semantics is the study and analysis of how language is used figuratively and literally to produce meaning. So, in a way, semantic rules make communication possible since they are rules that people have agreed on to give meanings to words. Semantic misunderstandings arise when people give different meanings to the same words or phrases.

When looking at how speech communities assign meanings to words, Ulmann (1964, p. 265) identified meaning as a verbal definition that is conventionally assignable to a form. Meaning can basically be divided into two: lexical and grammatical. Lexical meaning is the literal meaning of a word, as contained in the dictionary. It is the original meaning of a word which has not been diluted by any verbal or situational context. Grammatical meaning is the meaning conveyed in a sentence by word order and other grammatical measures. This implies that a word expressing the same idea can perform different syntactic functions.

O'Grady et al. (1966, p. 257) as cited in Tobing (2010) thinks differently about the existence of meaning. He viewed meaning as something that exists in the mind rather than the word spoken during speech. So, words 
mean different things to different people. The speaker and the listener may hold different meanings in their minds during a communicative event. This is the picture-producing power of arranged word.

Certainly, meaning is subject to change. The dominion of change over meaning is instant and unstoppable. When reviewing the nature of meaning, Nerlich \& Clarke identified that "the nature of meaning is change" and that "the explanation of meaning should be based on the fact that meaning is dynamic and ever-changing, "something" of which change seems to be an inherent property. That is, one can only explain what meaning is, by explaining how it changes" (Bouddisson, 2013, p. 40)

This led C.K Odgen and Richard (1946, p. 186-187) to combine twenty-two definitions of the word 'meaning', some of which were quoted by Leech $(1974$, p. 1) as;

-An intrinsic property.

-The other words annexed to a word in the dictionary.

-The connotation of a word.

-The place of anything in a system.

-The practical consequences of a thing in our future experience.

-That to which the user of a system actually refers.

-That to which the user of a symbol ought to be referring.

-That to which the user of the symbol believes himself to be referring.

-That to which the interpreter of a symbol:

a) refers

b) believes himself to be referring

c) believes the user to be referring

In view of this, we can deduce that semantics cannot be ignored or tagged as the weak point in the language. Our world revolves around meanings. Of its essence, Morris bravely stated; "we come then to conclusion that meaning is practically everything. We always see the meaning as we look, think in meanings as we think, act in terms of meaning when we act. Apparently, we are never directly conscious of anything but meanings" (Morris, 1946, p. 19).

Hence, meaning is an indispensable companion of language.

\section{Semantic Change}

Semantic change is the subfield of historical linguistics that investigates changes in words over time. Semantic changes occur when speakers attribute new meanings to extant expressions.Semantic changes have been scientifically studied for more than one hundred and fifty years. All along this history, successive generations of scholars have adopted at least three theoretical frameworks.

Chronologically, the first trend focused on the identification of the different kinds of semantic changes a lexeme can undergo. The second trend laid emphasis on the advocacy of cross-linguistic studies and the focus is on semantic field rather than isolated lexemes. The third trend is the cognitivist trend, which aims at explaining the cognitive mechanisms that underlie semantic change.Investigators of changes in meaning have established a set of semantic categories, such as 'generalization', in which the meaning and reference of a word widen over the years and 'specialization', in which the meaning of a word narrows over the years. Like any linguistic change, a 
semantic change is not acquired simultaneously by all members of a speech community. An innovation enters a language and spreads through the speech community along socially determined lines.

As well, semantic change is not necessarily a change in meaning per se, but the addition of a meaning to the semantic system or the loss of a meaning from the semantic system while the form remains constant. The original meaning of a form is not immediately displaced by the innovated meaning, but the two coexist for some time. It occurs in Yoruba language when native speakers adopt/innovate expressions and apply them to activities or conditions in their own social and cultural environment. When words in Yoruba undergo semantic change, it is often observed that there is no semantic similarity or connection between the new sense and the original. The alteration of meaning occur because words are constantly in use and what is intended by speakers is not exactly the same each time. So, if a different intention for a word is shared by the speech community and becomes established in usage, then, a semantic change has occurred.

Moreover, lexical change is probably the most frequent type of language change and the easiest to observe. For instance, we can make confident assertions about the age of a speaker who uses the word 'òsùpá' to refer to 'year', or the one who uses the word 'ojà' to refer to refer to 'marijuana'. This illustrates perfectly how words can virtually disappear or gradually shift in meaning and usage. Older speakers use vocabularies we might now consider a little outdated or tag as outright outdated while young speakers use vocabularies that the older ones might not even understand or tag as complex.

Also, the meaning of a word can either be slightly altered, or it can evolve greatly. While this can cause confusion and misunderstanding, it is also seen as a positive step forward in the growth and adaptation of languages.

In addition, semantic change can be influenced by a variety of factors, including culture, language interference, as well as the advancement of science and technology. Some words disappear completely from daily usage, thereby confirming the notion that language is fluid and ever-changing. The definitions and meanings behind words do not have set rules and guidelines, and are at the discretion of the society.

In conclusion, the reason for language change is that each generation has to learn a language for themselves and what they do is to construct a different version.

Palmer (1981) observed semantic change (as cited in Tobing, 2010, p. 16-17) and, argued four types of semantic change as follows;

\section{Generalization}

This is the broadening of the meaning of a word. The sphere of usage of such meaning increases, such that the word can be used in diverse contexts with a broader meaning rather than, the neural meaning. For example, the original meaning of the Yoruba word 'ọjà' is 'market'; a place where goods are sold, while the exact word 'ojà' has been broadened to mean 'weed'; a street name for 'marijuana'.

\section{Specialization}

This is the opposite of generalization. It occurs when the meaning of a word is narrowed into the same class. The sphere of usage of such meaning is decreased, so that a word can be used in fewer con texts other than before the change of meaning. The meaning of such a word is reshaped courtesy of the pressure of another word that had frequently co-occurred with it. For example, 'òsùpá' in Yoruba, has been known with the meaning 
'year' and 'moon' overtime. Now, the word 'moon' retained 'òsùpá' while the word 'year' is now referred to as 'ọdun'.

\section{Pejoration}

It is a process by which the meaning of a word worsens or degenerates, and has evolved to represent something less favourable or unpleasant than it originally did. For example, the Yoruba word 'olójà' refers to a seller of goods and it has a positive meaning, but the word 'olójà' now means 'prostitute', which has a negative meaning.

\section{Amelioration}

This is a process by which the meaning of a word improves or becomes elevated, and has evolved to represent something more favourable and pleasant than it originally refers to.

For example, in the sentence, "O ti tà ibon"(You have shot the gun), the Yoruba phrase 'ta ibon' means 'to shoot something with a gun'. It has a terrifying sense of hurting or killing someone. However, in the sentence "Dakẹ, o ti ta ibon"(Keep quiet, you have committed an error) probably uttered in the course of a communicative event. The phrase 'ta ibon' here means, 'to commit an error when speaking a foreign language'. In this sentence, the phrase 'ta ibon' does not have a terrifying sense as it was in the former sentence.

Factors that facilitate semantic change includes: Happening by chance, the need for a new meaning, scientific words, taboo, discontinuous of language, vagueness of meaning, loss of motivation, polysemy, ambiguous context,structure of the vocabulary, etc.

\section{Theoretical Framework}

The theoretical pivot of the phenomenon that produced semantic changes in Yoruba is that of language change, lexical expansion and innovation. The theory for this study is the Functional theory that was proposed by M. A. K. Halliday. He developed the theory in the early sixties (seminal paper, Halliday 1961). The theory posits that language changes according to the needs of its users. This mainly covers lexical change. This tend to take the form of new discoveries/learning/inventions, technological words and slangs.

Thus, this research is based on the four principles of functional linguistics. Functional linguistics holds that; language use is functional, its use is to make meanings, these meanings are influenced by the social and cultural context in which they are exchanged and it affirms that, the process of using language is a semiotic process; a process of making meaning by choosing.

According to Halliday (1975), language has developed in response to three kinds of social-functional 'needs.' The first is to be able to construe experience in terms of what is going on around us and inside us. The second is to interact with the social world by negotiating social roles and attitudes. The third and final need is to be able to create messages with which we can package our meanings in terms of what is 'New or Given', and in terms of what the starting point for our message is, commonly referred to as the 'Theme'. What is new or given here refers to the trend in the meaning of words. The existence of such meanings is deeply rooted in the realization that the initial meaning can no longer satisfy the needs of the language speakers.

\section{Methodology}

This research was done qualitatively and descriptively. The major purpose of descriptive research is description of the state of affairs as it exists at present. This paper focused on semantic analysis of the effect of semantic 
change in linguistic performance of Yoruba native speakers. A group conversations of people in their natural settings were observed.The population was randomly selected from bilinguals of Yoruba-English of obtained.The aim of analyzing the data is to find out the regular pattern so that the purpose of the study is achieved. The data are analyzed based on the functional theory proposed by M. A. K. Halliday, which posits that language changes according to the needs of its users, using: (1) New discoveries/learning/inventions (2) Technological words (3) Slangs as the features of analysis.

Thus, the purpose of the descriptive research is to make a description and paint systematically, the semantic changes observed in lexical items as well as the effectof meaning change in Yoruba-English speakers.

\section{Analysis}

\section{NEW DISCOVERIES/LEARNINGS/INVENTIONS (LEXICAL EXPANSION)}

1. Moon/Year

2. $1^{\mathrm{ST}} \mathrm{STAGE}$ : Òsùpá

Meaning: moon

$2^{\text {ND }}$ STAGE: Òsùpá

Meaning: year

CURRENT STAGE: 'Òsùpá' for 'moon' retained its meaning.

CURRENT STAGE: 'Òsùpá' which means 'year', evolved and 'ọdún' for 'year' emerged.

'Òsùpá' which means 'moon' is a universal word. There is no language that does not have a way of referring to this heavenly rounded light. So, the word 'òsùpá' for 'moon' existed before the word 'òsùpá' for 'year'

\section{Festival/Year}

$1^{\text {ST }}$ STAGE: OQdún

Meaning: festival

$2^{\mathrm{ND}}$ STAGE: Ọdún

Meaning: year

CURRENT STAGE: 'Ọdún' retained the meanings for both 'festival' and 'year'.

\section{Pot}

$1^{\text {ST }}$ STAGE: İsasùn

Meaning: A pot molded with clay that passes through a heated furnace during the making process. It is used for cooking soups and stews.

$2^{\mathrm{ND}} \mathrm{STAGE}$ : Ìkòkò

Meaning: A pot molded with clay and used for cooking all sorts of delicacies. It is especially used as a water pot that is often placed in a corner inside a house. A cup is often placed on it, and water drawn from it is always cool.

$3^{\text {RD }}$ STAGE: Apẹ

Meaning: A pot made with a metal that is usually round and deep; often has a handle and lid. 
CURRENT STAGE: 'İsasùn', 'ikòkò' and 'apẹ’ retained the meanings for 'pot'. Now, they refer to different kinds of pot. 'Ìsasùn' and 'ikòkò' are gradually disappearing and are used in different contexts; when referring to ancient practices or traditions. 'Apẹ' is taking the lead, and it is used frequently.

\section{Lamp}

$1^{\text {ST }}$ STAGE: Fìtílà

Meaning: Atype of lamp made with clay. This lamp was majorly used before the discovery of kerosene especially in Yoruba land, and it is often filled with palm oil. It was later called 'àtùpà'

$2^{\text {ND }}$ STAGE: Kádégbón (Jàngo)

Meaning: A type of lamp made with tin enclosed in wick. The tin is often filled with kerosene. It has a small opening at the top where the wick is lighted with a match stick to give light.

$3^{\text {RD }}$ STAGE: Àtùpà

Meaning: A type of lamp made with clay with an elongated tip which houses a wick. It is the wick that is lighted to give light. The lamp is filled with palm oil which serves as the fuel. It was initially known as 'fitílà' before it evolved and was named 'àtùpà'.

$4^{\mathrm{TH}}$ STAGE: Léntírìì

Meaning: A type of lamp that is pumped to give light. It is pumped like a bicycle tyre, and the more pumped it is, the more the brightness.

CURRENT STAGE: It was observed that the words 'fitílà' and 'léntírikì' are no longer in use, the words and the objects; 'kádégbón' and 'àtùpà' are used in different contexts and social situations. These words are gradually going into extinction as they have been replaced with electricity (iná èlétírìì), battery lamps and rechargeable lamps.

\section{Cup}

The word 'cup' passed through different lexical expansion. They are as follows;

$1^{\text {ST }}$ STAGE: Ikeemu

$2^{\text {ND }}$ STAGE: Ife

$3^{\text {RD }}$ STAGE: Koobu

CURRENT STAGE: The word 'koobu' for 'cup' is majorly in use now. It was borrowed through adaptation into the Yoruba vocabulary structure from the English word 'cup'.

\section{Container for fetching water}

$1^{\text {ST }}$ STAGE: Agbè (akèrèngbè)

Meaning: A container made from calabash.

$2^{\text {ND }}$ STAGE: Ìkòkò

Meaning: A container made from clay.

$3^{\text {RD }}$ STAGE: Ládugbó

Meaning: A four dimension container made from metal.

$4^{\mathrm{TH}}$ STAGE: Ike

Meaning: A container made from plastic. 
CURRENT STAGE: When it comes to containers for fetching water, 'ike' is majorly in use now. However, a container made with plastic can be called 'ladugbo' or 'baafu' by the elderly speakers. The choice is largely dependent on the speakers, and it varies from speaker to speaker.

\section{Kerosene}

$1^{\text {ST }}$ STAGE: Epo èbó.

"Epo èbó" when translated, literally means the 'fuel of the white'. The sellers often advertize this way; "Àrọkún epo èbó o". This means; "your container will be filled to the brim if you buy from me". This advertisement is literal, because your container being filled to the brim is dependent on the liters of kerosene you buy. So it is purely a marketing strategy.

$2^{\text {ND }}$ STAGE: Baafín

$3^{\text {RD }}$ STAGE: Karosín

'Karosín' is a borrowed form and it was borrowed through adaptation.

CURRENT STAGE: The word 'karosín' for 'kerosene' is mostly current and it is heard in speakers' daily conversations.

\section{Maizepudding}

$1^{\text {ST }}$ STAGE: Àbàrí

'Àbàr'’' is made from grinded maize. It is a meal made exactly like a beans pudding. Sellers often advertize this way; "Àbàrí tepo, tiyọ̣". This means; "Àbàrí is loaded with palm oil, and salt to taste”. This is just a marketing strategy to make buyers salivate and desire to buy. Later, 'àbàri' evolved and was called 'sapala'.

$2^{\text {ND }}$ STAGE: Sapala

Sapala is the same as 'àbàrí'.

CURRENT STAGE: Both words are used interchangeably. The preference of one over the other is dependent on the age of speakers.

\section{Beans pudding}

\section{$1^{\text {ST }}$ STAGE: Ọlẹ̀ (Ộlẹlệ)}

'ọ̀lẹ, also called 'ọ̀lẹlẹ' is made from grinding beans into a smooth paste, with the addition of seasoning, palm oil or vegetable oil, depending on individual preferences.

$2^{\text {ND }}$ STAGE: Mọinmọin

The word 'ọlẹ' evolved, and beans pudding got the name; 'mọinmọin'. It still has the exact processes of making the meal.

CURRENT STAGE: Both words are used interchangeably by native speakers.

\section{Cold pap (made into leaves)}

$1^{\text {ST }}$ STAGE: Oori

$2^{\text {ND }}$ STAGE: Ẹkọ-tútù

CURRENT STAGE: 'Ẹkọ-tútù' is now used by the majority of native speakers. Before one can come across the word 'oori' for cold pap, such a speaker will probably be between 60-80 years. Though, speakers that are not up to this age can recall the word 'oori', but not in a linguistic performance.

\section{Lime}


$1^{\text {ST }}$ STAGE: Orombo

$2^{\text {ND }}$ STAGE: Ọsàn wẹ́wẹ

CURRENT STAGE: Both words are used interchangeably by both the classical and contemporary generation.

\section{Compound}

$1^{\text {ST }}$ STAGE: Káà

$2^{\text {ND }}$ STAGE: Agbolé

'Agbolé' is from 'Agbo (outside) + Ile (house)=Agbolé (compound)'.

CURRENT STAGE: 'Agbolé' is commonly used now.

\section{Broom}

$1^{\text {ST }}$ STAGE: Șașara

'Ṣașara' is a type of broom gotten from a particular tree called 'Igi Ọlọsẹpotu'. The plant is often dried and tied with a rope. It is usually used to sweep the compound.

$2^{\text {ND }}$ STAGE: Ọwọ

'Ọwọ' is gotten from palm tree. It is mainly extracted from its fronds. At a point, 'Ọwộ' is called 'Ìgbálẹ’' by some speakers.

$3^{\text {RD }}$ STAGE: İgbálẹ

'Ìgbálẹ’' is the same object as 'Ọwọ’'

CURRENT STAGE: 'Ọwọ’ and 'Ìgbálẹ’' are used interchangeably by speakers.

\section{Underwear skirt (females)}

$1^{\text {ST }}$ STAGE: Ìlábìrù

$2^{\text {ND }}$ STAGE: Tòbí

$3^{\text {RD }}$ STAGE: Yẹ̀rì

CURRENT STAGE: 'Yệrì' is majorly in use now.

\section{Yam flour meal/Cassava flour meal}

This is made by boiling water and adding yam flour/cassava flour which is mixed together to form a smooth paste.

$1^{\text {ST }}$ STAGE: Ọkà

$2^{\mathrm{ND}} \mathrm{STAGE}$ : Àmàlà

CURRENT STAGE: 'Ọkà' and 'Àmàlà' is used interchangeably, and it varies from speaker to speaker.

\section{Body cream}

Different materials are used as cream. They are as follows:

$1^{\text {ST }}$ STAGE:Osùn (camwood)

$2^{\text {ND }}$ STAGE: Àdí-àgbon (coconut oil)

$3^{\text {RD }}$ STAGE: Ìpara

CURRENT STAGE: The use of any of these is dependent on the type of body cream that is being used. However, 'ìpara' is used for all sort of cream except that of 'Osùn' (camwood) and 'Àdí-àgbon' (coconut oil).

\section{Maize}


$1^{\text {ST }}$ STAGE: Yangan

$2^{\text {ND }}$ STAGE: Erín

$3^{\text {RD }}$ STAGE: Àgbàdo

CURRENT STAGE: 'Yangan' is mostly used by elderly speakers. 'Erín' and ‘Àgbàdo' is majorly in use now. The use of any of these is dependent on the preference of the speakers.

\section{Trousers}

$1^{\text {ST }}$ STAGE: Kẹmbẹ̀

'Kẹ̀mbẹ' is quite baggy and does not reach the ankle.

$2^{\text {ND }}$ STAGE: Sọ́rọ

$3^{\text {RD }}$ STAGE: Sòkòtò

CURRENT STAGE: 'Sòkòtò' is majorly in use now. The use of 'Kẹmbẹ' and 'Sọrọ' is dependent on the type of styles in question and the age of speakers.

\section{Uniformed clothing}

Uniformed clothing are used by the Yoruba people for ceremonies and festivals.

$1^{\text {ST }}$ STAGE: Asọ-ẹgbẹjọdá

$2^{\text {ND }}$ STAGE: Asọ-ẹbí

CURRENT STAGE: Asọ-ẹbí is majorly in use.

\section{Locust beans}

Locust beans are condiments added to foods and soups because of its special smell and nutritional value.

$1^{\text {ST }}$ STAGE: Irú

$2^{\text {ND }}$ STAGE: Ìsebẹ̀

CURRENT STAGE: Both 'Irú' and 'Ìsebẹ’ are used interchangeably by native speakers.

\section{Motorcycle}

$1^{\text {ST }}$ STAGE: Tatagànràn

$2^{\mathrm{ND}} \mathrm{STAGE}$ : Álùpùpù

CURRENT STAGE: ‘Álùpùpù' is majorly in use now.

\section{Door}

$1^{\text {ST }}$ STAGE: Àfàsé

$2^{\text {ND }}$ STAGE: Ilẹkùn

CURRENT STAGE: 'Ilệkùn' is majorly in use now.

\section{Sieve for yam flour/cassava flour}

$1^{\text {ST }}$ STAGE: Kọ̀nkọsọ̀

$2^{\text {ND }}$ STAGE: Ajọ-ìkùlùbọ́

CURRENT STAGE: 'Ajọ-ikùlùbọ’' is widely used now, while 'Kọnkộsọ’ is no longer in use.

\section{Sewing needle}

$1^{\text {ST }}$ STAGE: Ọ̀pọrọ̀

2N STAGE: Abẹrẹ́ 
CURRENT STAGE: 'Abẹrẹ' is majorly in use now.

\section{TECHNOLOGICAL WORDS}

\begin{tabular}{|c|c|c|}
\hline Electricity & - & Iná-mònàmóná \\
\hline Philosophy & - & Àròjinlẹ \\
\hline Science & - & İmọjìnlẹ̀ \\
\hline Academy & - & Ilé-ẹkộ \\
\hline Technique & - & Ọ̀nà \\
\hline Earth & - & Ayé \\
\hline World & - & Àgbáyé \\
\hline Star & - & İràwọ \\
\hline Galaxy & - & Àjọọàwọ̀ \\
\hline Tool/Device & - & Ẹ̀rọ \\
\hline Diplomacy & - & Ìfọ̀rọwérọ \\
\hline Civilization & - & Ọ̀làjú \\
\hline Thesis & - & Àlàyé-ìjìnlè \\
\hline High-way & - & Òpòpónà \\
\hline Subject & - & Àșàyàn-ệkọ́ \\
\hline Democracy & - & Ìjọba-alágbádá \\
\hline Hospital & - & Ilé-ìwòsàn \\
\hline Air-conditioner & - & Ẹ̀rọ-amúlétutù \\
\hline Phone & - & Ẹ̀rọ-ibánisọ̀rọ̀ \\
\hline Blender & - & Ẹrọ-ìlọta \\
\hline Television & - & Ẹ̀rọ-amóhùnmá \\
\hline
\end{tabular}

\subsubsection{SLANGS}

$\begin{array}{lll}\text { Words } & \text { Literal meanings } & \text { Extended meanings } \\ \text { Rógo } & \text { Behold glory } & \text { Trouble } \\ \text { Gán } & \text { Sting } & \text { Deceive } \\ \text { Eja } & \text { Fish } & \text { Marijuana } \\ \text { Gbe sẹnu } & \text { Put in mouth } & \text { Drink alcohol } \\ \text { Ọsẹ } & \text { Soap } & \text { Contempt } \\ \text { Ta lẹ́nu } & \text { Spicy } & \text { Sexy } \\ \text { Ògẹ̀dẹ } & \text { Banana } & \text { Penis } \\ \text { Ọjà } & \text { Market } & \text { Weed (marijuana) } \\ \text { Ọlọjà } & \text { Seller } & \text { Prostitute } \\ \text { Epo } & \text { Palm oil } & \text { Bleaching cream }\end{array}$




\begin{tabular}{|c|c|c|}
\hline Gbẹsẹ̀ & Adjust one's leg & A form of dance \\
\hline Ajá & Dog & Prostitute \\
\hline Gé ìgò & To break a bottle & Drink alcohol \\
\hline Sisí pẹlẹbẹ & Slim lady & Groundnut candy \\
\hline Jẹ̀ gò & Eat a bottle & Forfeit/lose something \\
\hline Gbé áyán mì & Swallow a cockroach & Pregnant \\
\hline Ìjẹ & Edible & Prey \\
\hline $\mathrm{Ru}$ po & Carry potty & To fail woefully \\
\hline Sán gbó & Cut the bush & Retake an exam \\
\hline Gbé gbó & Gather dried plant & Failure \\
\hline Orombo & Lime & Small breast (female) \\
\hline İbẹpẹ & Pawpaw & Extra large breast (female) \\
\hline Ọsàn & Orange & Big breast (female) \\
\hline Ó pọ̀ & Many/plenty & Endowed (female) \\
\hline \multirow[t]{2}{*}{ Ó pọ̀ dánú } & Filled to the brim & i. Heavily endowed female \\
\hline & & ii. Well dressed (male/female) \\
\hline Sọ̀rọ sókè & Speak louder & Lend your voice \\
\hline Jẹ ojú & Eat an eye & Put to shame/surprise/disappoint \\
\hline Gba tị̀ & Agree to an opinion & Love/support \\
\hline Kó jẹ & Eat & Like/admire \\
\hline Ojọ́ iwájú & Future & Breast \\
\hline Èỳ̀n ọ̣la & After tomorrow & Butt (female) \\
\hline Kálá & Harvest okro & Stingy \\
\hline Jẹ́ dòdò & Eat plantain & Love/admire \\
\hline Saka & Sack (bag) & Good \\
\hline Gbe fun & Give it & To lie \\
\hline Kó rodo & Pack pepper & Not smart/foolish \\
\hline Ẹlẹ & Patience & A beautiful lady \\
\hline Ọjà alẹ́ & Night market & Prostitution \\
\hline Òlẹlẹ & Beans pudding & Woman \\
\hline Gbéra & Lift one's body & e at a fast pace \\
\hline
\end{tabular}

\section{Findings and conclusion}

This study has examined the case of different meanings attached to words in Yoruba language, as well as how some of these words disappear or become established in usage. This has been achieved by looking at terms used as technological words, slangs, as well as lexical expansions that are as a result of new inventions. These are encapsulated to cover strategic areas (social and cultural) which dominate everyday activities of people. 
Similarly, basic and important factors which are responsible for deviations have been revealed. These factors include; the need for a new meaning, happening by chance, level of exposure, scientific words, level of education, taboo, and the like.

Moreover, meaning is an indispensable companion of language, therefore, this study has shown that semantic change in Yoruba language has been influenced by factors such as; culture, language interference, as well as the advancement of science and technology. Some words disappear completely from daily usage, thereby confirming the notion that language is fluid and ever-changing.

Also, the definitions and meanings behind words do not have set rules and guidelines, and are at the discretion of the society. It has been discovered that, if a different intention for a word is shared by the speech community, and becomes established in usage, then, a semantic change has occurred. This is because as society evolves so does language and language changes to meet up with the immediate need of the society.

In view of this, older speakers use vocabularies that are considered a little outdated, or tagged as totally outdated while the contemporary speakers use vocabularies that the older generations might not even understand or tag as fragments of the Yoruba language. As a result of this, confident assertions about the age of a speaker who uses the word 'òsùpá' to refer to 'year', and the one who uses the word 'ojà' to refer to 'marijuana' can be made. This illustrates perfectly how words can virtually disappear or gradually shift in meaning and usage.

However, as much as semantic change in Yoruba language exists, the classical and contemporary generations are expected to fill up the semantic gap between them. This will help native speakers as well as learners of the language to be involved in the understanding of communicative events in the language.

Finally, the limitations of this study is a challenge to direct critical attention towards a comprehensive study of semantic change in Yoruba language, and also in its proper documentation and publication of materials on semantic change.

\section{Recommendations}

Based on the foregoing findings, it is recommended that;

Since the internet can ultimately be likened to the dictionary of semantic change, it is recommended that lexicographers should consider the internet when sourcing for words. There should be a Dictionary of Semantic Change in Yoruba language, which should be reviewed and updated from time to time. This will help each generation to keep track of meanings. Another recommendation is that there should be a Dictionary of Slangs in Yoruba language. Learners of the language are mostly taught the literal meanings of words, and so they seem lost in a communicative event. This is also evident in native speakers who have little or no idea on the changes in meanings. Finally, it is recommended that the gap between the classical and contemporary generation of Yoruba-English speakers should be filled by striking an optimal balance between the two generations through books and the mass media. 


\section{References}

Ajayi, J.F. (1960). How Yorùbá was Reduced to Writing. Odu, No. 8.

Bossidan, A. (2013). Dynamics of semantic change.Laboratoire sur le Langage, le Cerveau et la Cognition (L2C2)Institut des Sciences Cognitives, 28-40

Cambridge Biographical Dictionary. (1990). ( $5^{\text {th }}$ ed.). Larousee Kingfisher + chambers: Magnus Magnusson.

Chomsky, N. (1965). Aspects of Theory of Syntax. Cambridge. Mass.: MIT Press.

C.K. Ogden \& I.A. Richards. (1946), The Meaning of Meaning. ( $8^{\text {th }}$ ed.). New York, CA: Harcourt, Brace \& World, Inc.

Durkheim, É. (1907). Les Règles De La Méthode Sociologique. Alcan.

Halliday, M.A.K. (1961). Categories of the theory of grammar. Reprinted as Chapter 2 in M.A.K. Halliday (2002), On grammar, Volume 1 of The collected works of M.A.K Halliday edited by Jonathan J. Webster. London \&New York: Continuum.

(1975). Learning how to mean. London: Edward Arnold. Reprinted in M.A.K. Halliday (2003): The language of early childhood, Volume 4 of The collected works of M.A.K. Halliday edited by Jonathan J. Webster. London \& New York: Continuum.

Johnson, S. (1921). The History of the Yorùbás. Lagos: CSS Bookshops.

Littré, E. (1888). Comment Les Mots Changent De Sens. C. Delagrave.

Löbner, S. (2002). Understanding Semantics. London: Hodder Arnold.

Magué, J. P. (2005). Changements Sémantiques et Cognition: Différentes Méthodes pour Différentes Échelles Temporelles. Ph.D. diss., Université Lyon 2.

Marshall, C. \&Rossman, G.B. (1989).Designing Qualitative Research. Newbury Park, C.A: Sage.

Meillet, A. (1906). Comment les Mot Changent de Sens. Linguistique Historique et Linguistique Generale.

Moleong, L.J. (2011). Methodologi Penelitian Kualitatif Edisi Revisi. Bandung: PT. Remaja Rosdakaya.

Morris, C.W. (1946). Signs, Language and Behaviour. New York: Prentice-Hall.

Nerlich, B.\& D. Clarke. (1988). A dynamic model of semantic change. Journal of Literary Semantics.

Ogden, C. \& Richards, I. (1946), The Meaning of Meaning. ( $8^{\text {th }}$ ed.). New York, CA: Harcourt, Brace \& World, Inc.

Ogunleke, O. (2008). British and Nigerian English: A Fundamental Distinction. A Thesis Submitted to the Department of Linguistics and Communication Studies: University of Port-Harcourt.

Palmer, F. (1981). Semantics. Cambridge: Cambridge University Press.

Sudaryanto. (1993). Methode dan aneka teknik analisis bahasa: Pengantar penelitian wahana kebudayaan secara linguistis. Yogyakarta: Duta Wacana University Press.

Sweetser, E. (1990). From Etymology to Pragmatics: Metaphorical and Cultural Aspects of Semantic Structure. Cambridge, UK: Cambridge University Press.

Tobing, S. (2010). Semantic change and meaning shift analysis on film making terms. A Thesis Submitted to the English Department: Diponegoro University.

Traugott, E. C. \& R. B. Dasher (2002). Regularity in Semantic Change. Cambridge studies in linguistics. Cambridge, UK: Cambridge University Press. 
Ulmann, S. (1962). Language and Style. (1 ${ }^{\text {st }}$ ed.). UK: Basil Blackwell.

(1972). Semantics: An Introduction to the Science of Meaning. Oxford: Basil Blackwell.

Viberg, A. (1983). The Verbs of Perception: A Typological Study. Linguistics. 